\title{
Susceptibility of four Ipomoea genus weed species to the herbicides saflufenacil or flumioxazin
}

Saul Jorge Pinto de Carvalho ${ }^{1}$

Leonardo Ferreira Nery²

Carlos Alberto Borges Madeira ${ }^{3}$

Jeisiane de Fátima Andrade 4

Jéssica Cursino Presoto 5

\section{Abstract}

Among weeds commonly found in Brazil that directly interfere on agriculture, those classified in Convolvulaceae Family may be highlighted, particularly Ipomoea L. genus, popularly known as morning glories. Flumioxazin and saflufenacil are herbicide molecules registered to control these weeds. In this context, this work was developed with the objective of evaluating the susceptibility of four Ipomoea genus weed species to the herbicides flumioxazin and saflufenacil. Two similar and independent experiments were performed in 2017, adopting completely randomized blocks and four replicates. Treatments were organized according to an $8 \times 4$ factorial scheme, which eight were the rates of each herbicide and four were the weed species of Ipomoea genus (I. hederifolia, I. nil, I. quamoclit and I. triloba). The following rates were adopted to saflufenacil (g ha-1): 0, 1.5, 3.0, $6.1,12.3,24.5,49.0$ and 98.0. The rates adopted to flumioxazin were ( $\mathrm{g} \mathrm{ha}^{-1}$ ): $0,3.75,7.5,15.0$, 30.0, 60.0, 120.0 and 480.0. Ipomoea genus weed species were completely controlled by the herbicides saflufenacil and flumioxazin, which may be considered excellent alternatives to control morning glories. I. triloba and I. nil were identified as the least sensible species to flumioxazin at the rate of $3.75 \mathrm{~g} \mathrm{ha}^{-1}$; lower control of $I$. triloba was also identified with $7.5 \mathrm{~g}^{-1} \mathrm{a}^{-1}$ of flumioxazin; rates equal to or higher than $15.0 \mathrm{~g} \mathrm{ha}^{-1}$ promoted total control of weeds.

Keywords: PPO. Morning glory. Chemical control. Efficacy. Post-emergence.

\section{Introduction}

In modern agriculture, several biotic factors may interfere on crop yield, and among these factors, weed competition may be detached. Losses caused by weeds are not only connected to light, water and nutrients competition, but also to a set of environmental interferences related to direct effects, like allelopathy, or indirect effects, like hosting insects or diseases and harvest problems (VASCONCELOS; SILVA; LIMA, 2012).

1 Instituto Federal de Educação, Ciência e Tecnologia do Sul de Minas Gerais - IFSULDEMINAS, Campus Machado. Professor Doutor. sjpcarvalho@yahoo.com.br. Rod. Machado-Paraguaçu,km. 3, 37750-000, Machado/MG. 
Yield losses related to weed interference became herbicide application an essential and generalized practice (SCOTT; VAN DEYNZE, 2017). High efficacy of herbicides minimizes yield losses and reduces the costs of production if compared to other practices of weed control.

Species classified in Convolvulaceae family are among weeds commonly found in Brazil that directly interfere on agriculture. Convolvulaceae family is constituted by 56 genera and about 1,840 species, widely distributed in tropical and temperate regions (STAPLES; BRUMMITT, 2007). These plants are herbs or shrubs, annual or perennial, frequently with climbing habit, occasionally trees or holoparasites (Cuscuta spp. L.). Leaves are mostly alternate, simple and with absent stipules, sometimes latex is present. Flowers are gamopetals, campanulated or infundibiliform, with prominent mesopetal veins, epipetal stamens and super-ovary and generally fruits are capsular (AUSTIN, 2004; SOUZA; LORENZI, 2005).

Convolvulaceae species of Ipomoea genus are commonly known as morning glories or bindweeds. These plants naturally have higher tolerance to glyphosate (EPSP-inhibiting herbicide), in order that alternative herbicides or mixtures have been adopted to reach adequate control. In Brazil, saflufenacil and flumioxazin may be highlighted among herbicides registered to control Ipomoea species. These molecules are inhibitors of protoporphyrinogen oxidase (PPO - Group E), which is an enzyme that oxidizes protoporphyrinogen IX (PPGIX) to produce protoporphyrin IX (PPIX) in the chloroplasts. PPO is the last enzyme in the common pathway of chlorophyll and heme biosynthesis (HAO et al., 2011), route that is also known as porphyrin and tetrapyrroles pathway (MEROTTO JÚNIOR; VIDAL, 2001).

PPO-inhibiting herbicides have some advantages to agricultural use, such as: low toxicity to mammals, efficacy in low concentrations, broad spectrum of control, fast action on weeds, and possibility of soil effect which allows weed control in pre-emergence condition. Still, PPO herbicides select weed resistance at a significantly lower rate when compared to other modes of action (HAO et al., 2011; SALAS et al., 2016).

In Brazil, PPO-inhibiting herbicides are important tools for weed control in several crops, such as soybean, dry beans, sugarcane, cotton, coffee, and rice. Due to constant identification of weeds resistant to other modes of actions, PPO-inhibiting herbicides are frequently recommended as alternative molecules to contribute on prevention and management of these reports (VIDAL; MEROTTO JÚNIOR; FLECK, 1999).

Therefore, these herbicides are considered excellent alternatives for post-emergence control of Ipomoea genus weed species (CHRISTOFFOLETI et al., 2006; RODRIGUES; ALMEIDA, 2011). However, post-emergence efficacy is subjected to factors related to the phenological stage of the plants at the time of application and to differential susceptibility of weed species (MAYO et al., 1995; CARVALHO et al., 2006).

Evaluating the susceptibility of Ipomoea species to new herbicide molecules becomes relevant once weed species may have differential susceptibility to herbicides (CARVALHO et al., 2006; CHRISTOFFOLETI et al., 2006). In this context, this work was developed with the objective of evaluating the susceptibility of four Ipomoea genus weed species to the herbicides flumioxazin and saflufenacil.

\section{Material and methods}

Two similar and independent experiments were developed in a greenhouse of the Federal Institute of Education, Science and Technology of the South of Minas Gerais, Machado Campus State of Minas Gerais (2140'S; 45055'W; 850 m of altitude), Brazil. Both trials were carried out in the first semester of 2017. The first trial was conducted between February and April and it evaluated the performance of saflufenacil. The second trial evaluated the performance of flumioxazin, 
between April and July. Weeds of Ipomoea genus (morning glory) were adopted as bioindicators, which seeds were acquired commercially.

Seeds of four morning glory species were distributed in 2.0L plastic trays, fulfilled with commercial substrate. When seedlings reached the phenological stage of one expanded leaf, they were transplanted to the plots where they remained up to the end of the trials, at the density of three plants per pot. Plots consisted of 1.0L plastic pots, filled with mixture of commercial substrate, clay sieved soil and vermiculite (6:3:1), properly fertilized. After transplant, plots were daily irrigated.

Treatments of both experiments were organized according to an $8 \times 4$ factorial scheme, which 8 were the rates of each herbicide and 4 were the species of Ipomoea genus (. hederifolia, I. nil, I. quamoclit and I. triloba). The following rates were adopted to saflufenacil (g ha-1): 0, 1.5, 3.0, $6.1,12.3,24.5,49.0$ and 98.0. Rates adopted to flumioxazin were (g ha $\left.{ }^{-1}\right): 0,3.75,7.5,15.0$, 30.0, 60.0, 120.0 and 480.0. Experimental design of completely randomized blocks was adopted with four replicates, resulting on 128 plots each experiment.

Herbicide application was performed on plants with four expanded leaves on March $10^{\text {th }}$ and May $10^{\text {th }}, 2017$, respectively, for saflufenacil and flumioxazin. Application was carried out with a $\mathrm{CO}_{2}$-pressurized backpack sprayer, coupled to a single nozzle, model TeeJet XR 110.02, positioned at $0.50 \mathrm{~m}$ above the targets, with relative spray consumption of $200.0 \mathrm{~L} \mathrm{ha}^{-1}$. In all treatments, deionized water was used to prepare the solutions, to avoid contamination.

Percent control was evaluated at 7, 14 and 28 days after application (DAA), as well as residual dry mass at 28 DAA. For percent control, 0\% was attributed to plants with absence of symptoms and $100 \%$ to death plants, according to the recommendation of Brazilian Weed Science Society (SBCPD, 1995). Plant residual mass was collected from the plots and dried in an oven at $70^{\circ} \mathrm{C}$ for 72 hours. Mass of dry matter was corrected to percent values by comparing the mass obtained on herbicide treatments with mass of the check plots, considered $100 \%$.

Independently of each experiment, data was submitted to the application of F-test in analysis of variance, followed by the cluster Test of Scott-Knott (SCOTT; KNOT, 1974). When relevant, quantitative variables were adjusted to non-linear regressions. All statistical analyzes were performed adopting $5 \%$ of significance.

\section{Results and discussion}

In both experiments, rate effect was significant at $\mathrm{F}$ test for all evaluations of control. However, non-linear regressions were not fitted, once efficacy values below 50\% were not identified, even in the lowest rates, what is one of the assumptions of the mathematical model. In the absence of control values below $50 \%$, the adoption of non-linear regressions becomes incorrect (CHRISTOFFOLETI et al., 2016). These results are consequence of the high efficacy PPO-inhibiting herbicides have on control of Ipomoea genus, according to observations of Christoffoleti et al. (2006) and Nicolai et al. (2013).

At 7 DAA, rate-species interaction effect was identified in both experiments, what justified the factorial decomposition (Tables 1 and 2). In this first evaluation, I. hederifolia was the least susceptible species to saflufenacil, at the rate of $6.1 \mathrm{~g} \mathrm{ha}^{-1}$. For the other species, all the rates promoted excellent control, always above $98.0 \%$ (Table 1). Regarding to flumioxazin, also at 7 DAA, lower susceptible of $I$. triloba was detected at the rates of 3.75 and $7.5 \mathrm{~g} \mathrm{ha}^{-1}$. At the rate of $3.75 \mathrm{~g} \mathrm{ha}^{-1}$, lower susceptibility of $I$. nil was also observed, without difference to $I$. triloba (Table 2).

At 14 DAA, only isolated effect of rate was identified for saflufenacil experiment, without species nor interaction effects. Saflufenacil efficacy values were completely satisfying to control all the 
morning glory species (Table 3). Regarding to flumioxazin, results detected at 14 DAA were similar to those registered at 7 DAA evaluation, at which lower susceptibility of $l$. triloba was identified at the rates of 3.75 and $7.5 \mathrm{~g} \mathrm{ha}^{-1}$; and $I$. nil at the rate of $3.75 \mathrm{~g} \mathrm{ha}^{-1}$ (Table 4).

Table 1 - Efficacy of saflufenacil on four weed species of Ipomoea genus, evaluated at 7 days after application (DAA). Machado/MG, 2017.

\begin{tabular}{ccccc}
\hline $\begin{array}{c}\text { Rates } \\
\left(\mathbf{g ~ h a}^{-1}\right)\end{array}$ & \multicolumn{4}{c}{ Species $^{1}$} \\
\cline { 2 - 5 } I. hederifolia & l. nil & l. quamoclit & I. triloba \\
\hline Check Plots & $0.0 \mathrm{C} \mathrm{a}$ & $0.0 \mathrm{~B} \mathrm{a}$ & $0.0 \mathrm{~B} \mathrm{a}$ & $0.0 \mathrm{~B} \mathrm{a}$ \\
1.5 & $99.5 \mathrm{~A} \mathrm{a}$ & $100.0 \mathrm{~A} \mathrm{a}$ & $99.3 \mathrm{~A} \mathrm{a}$ & $99.0 \mathrm{~A} \mathrm{a}$ \\
3.0 & $100.0 \mathrm{~A} \mathrm{a}$ & $100.0 \mathrm{~A} \mathrm{a}$ & $99.0 \mathrm{~A} \mathrm{a}$ & $99.5 \mathrm{~A} \mathrm{a}$ \\
6.1 & $94.5 \mathrm{~B} \mathrm{~b}$ & $99.0 \mathrm{~A} \mathrm{a}$ & $99.0 \mathrm{~A} \mathrm{a}$ & $99.3 \mathrm{~A} \mathrm{a}$ \\
12.3 & $99.3 \mathrm{~A} \mathrm{a}$ & $99.5 \mathrm{~A} \mathrm{a}$ & $98.5 \mathrm{~A} \mathrm{a}$ & $98.3 \mathrm{~A} \mathrm{a}$ \\
24.5 & $99.5 \mathrm{~A} \mathrm{a}$ & $99.3 \mathrm{~A} \mathrm{a}$ & $99.5 \mathrm{~A} \mathrm{a}$ & $99.0 \mathrm{~A} \mathrm{a}$ \\
49.0 & $99.0 \mathrm{~A} \mathrm{a}$ & $100.0 \mathrm{~A} \mathrm{a}$ & $99.3 \mathrm{~A} \mathrm{a}$ & $99.5 \mathrm{~A} \mathrm{a}$ \\
98.0 & $99.0 \mathrm{~A} \mathrm{a}$ & $100.0 \mathrm{~A} \mathrm{a}$ & $99.3 \mathrm{~A} \mathrm{a}$ & $99.3 \mathrm{~A} \mathrm{a}$ \\
\hline $\mathrm{F}_{\mathrm{sp}}=4.049^{*}$ & $\mathrm{~F}_{\text {rate }}=17,633.214^{*}$ & $\mathrm{~F}_{\text {int }}=2.828^{*}$ & CV $(\%)=1.06$ \\
\hline
\end{tabular}

*Significant at $5 \%$ of probability; ${ }^{1}$ Means followed by the same letter, uppercase in the columns and lowercase in the rows, do not differ according to Scott-Knott's cluster test, with 5\% significance.

Source: Elaborated by the authors (2017).

Table 2 - Efficacy of flumioxazin on four weed species of Ipomoea genus, evaluated at 7 days after application (DAA). Machado/MG, 2017

\begin{tabular}{ccccc}
\hline Rates & \multicolumn{4}{c}{ Species $^{1}$} \\
\cline { 2 - 5 } (g ha $\left.^{-1}\right)$ & I. hederifolia & I. nil & l. quamoclit & I. triloba \\
\hline Check Plots & $0.0 \mathrm{~B} \mathrm{a}$ & $0.0 \mathrm{C} \mathrm{a}$ & $0.0 \mathrm{~B} \mathrm{a}$ & $0.0 \mathrm{C} \mathrm{a}$ \\
3.75 & $97.3 \mathrm{~A} \mathrm{a}$ & $90.0 \mathrm{~B} \mathrm{~b}$ & $97.5 \mathrm{~A} \mathrm{a}$ & $91.0 \mathrm{~B} \mathrm{~b}$ \\
7.5 & $99.0 \mathrm{~A} \mathrm{a}$ & $98.3 \mathrm{~A} \mathrm{a}$ & $97.3 \mathrm{~A} \mathrm{a}$ & $87.5 \mathrm{~B} \mathrm{~b}$ \\
15.0 & $99.3 \mathrm{~A} \mathrm{a}$ & $99.5 \mathrm{~A} \mathrm{a}$ & $98.8 \mathrm{~A} \mathrm{a}$ & $98.3 \mathrm{~A} \mathrm{a}$ \\
30.0 & $99.3 \mathrm{~A} \mathrm{a}$ & $99.5 \mathrm{~A} \mathrm{a}$ & $99.8 \mathrm{~A} \mathrm{a}$ & $98.8 \mathrm{~A} \mathrm{a}$ \\
60.0 & $99.8 \mathrm{~A} \mathrm{a}$ & $99.5 \mathrm{~A} \mathrm{a}$ & $99.5 \mathrm{~A} \mathrm{a}$ & $99.8 \mathrm{~A} \mathrm{a}$ \\
120.0 & $99.8 \mathrm{~A} \mathrm{a}$ & $99.0 \mathrm{~A} \mathrm{a}$ & $99.8 \mathrm{~A} \mathrm{a}$ & $99.5 \mathrm{~A} \mathrm{a}$ \\
480.0 & $99.8 \mathrm{~A} \mathrm{a}$ & $99.8 \mathrm{~A} \mathrm{a}$ & $99.8 \mathrm{~A} \mathrm{a}$ & $100.0 \mathrm{~A} \mathrm{a}$ \\
\hline $\mathrm{F}_{\mathrm{sp}}=4.650^{*}$ & \multicolumn{2}{c}{$\mathrm{F}_{\text {rate }}=2,361.091^{*}=2.516^{*}$} & $\mathrm{CV}(\%)=3.33$ \\
\hline
\end{tabular}

*Significant at $5 \%$ of probability; ${ }^{1}$ Means followed by the same letter, uppercase in the columns and lowercase in the rows, do not differ according to Scott-Knott's cluster test, with $5 \%$ significance.

Source: Elaborated by the authors (2017). 
Table 3 - Efficacy of saflufenacil on four weed species of Ipomoea genus, evaluated at 14 days after application (DAA). Machado/MG, 2017.

\begin{tabular}{|c|c|c|c|c|c|}
\hline \multirow{2}{*}{$\begin{array}{c}\text { Rates } \\
\left(\mathrm{g} \mathrm{ha}^{-1}\right)\end{array}$} & \multicolumn{4}{|c|}{ Species $^{1}$} & \multirow{2}{*}{ Means } \\
\hline & I. hederifolia & I. nil & 1. quamoclit & I. triloba & \\
\hline Check Plots & 0.0 & 0.0 & 0.0 & 0.0 & $0.0 \mathrm{C}$ \\
\hline 1.5 & 100.0 & 100.0 & 99.8 & 100.0 & $99.9 \mathrm{~A}$ \\
\hline 3.0 & 100.0 & 100.0 & 100.0 & 100.0 & $100.0 \mathrm{~A}$ \\
\hline 6.1 & 97.8 & 100.0 & 99.0 & 100.0 & $99.2 \mathrm{~B}$ \\
\hline 12.3 & 99.8 & 100.0 & 99.5 & 100.0 & $99.8 \mathrm{~A}$ \\
\hline 24.5 & 100.0 & 100.0 & 100.0 & 100.0 & $100.0 \mathrm{~A}$ \\
\hline 49.0 & 100.0 & 100.0 & 100.0 & 100.0 & $100.0 \mathrm{~A}$ \\
\hline 98.0 & 100.0 & 100.0 & 100.0 & 100.0 & $100.0 \mathrm{~A}$ \\
\hline $\mathrm{F}_{\mathrm{sp}}=1.626^{\mathrm{NS}}$ & \multicolumn{2}{|c|}{$F_{\text {rate }}=40,574.652^{*}$} & $=1.190^{\mathrm{NS}}$ & \multicolumn{2}{|c|}{$\mathrm{CV}(\%)=0.70$} \\
\hline
\end{tabular}

NsNot significant at $\mathrm{F}$ test; *Significant at $5 \%$ of probability; ${ }^{1}$ Means followed by the same letter in the columns do not differ according to Scott-Knott's cluster test, with $5 \%$ significance.

Source: Elaborated by the authors (2017).

At the last evaluation of efficacy, performed at 28 DAA, all the rates of saflufenacil reached $100 \%$ of control without distinction of species, what resulted on total absence of dry mass on the plots (data not presented). High susceptibility of Ipomoea genus weed species to PPO-inhibiting herbicides is well documented in scientific literature, however differential susceptibility may also be found frequently (CHRISTOFFOLETI et al., 2006). In this work, saflufenacil high efficacy must be detached, what became impossible to differentiate species even at the lowest rate, such as $1.5 \mathrm{~g} \mathrm{ha}^{-1}$.

Table 4 - Efficacy of flumioxazin on four weed species of Ipomoea genus, evaluated at 14 days after application (DAA). Machado/MG, 2017.

\begin{tabular}{ccccc}
\hline \multirow{2}{*}{$\begin{array}{c}\text { Rates } \\
\text { (g ha }\end{array}$ ) } & \multicolumn{4}{c}{ Species $^{1}$} \\
\cline { 2 - 5 } Check Plots & I. hederifolia & I. nil & l. quamoclit & I. triloba \\
3.75 & $0.0 \mathrm{~B} \mathrm{a}$ & $0.0 \mathrm{~B} \mathrm{a}$ & $0.0 \mathrm{~B} \mathrm{a}$ & $0.0 \mathrm{C} \mathrm{a}$ \\
7.5 & $100.0 \mathrm{~A} \mathrm{a}$ & $85.8 \mathrm{~B} \mathrm{C}$ & $99.0 \mathrm{~A} \mathrm{a}$ & $92.5 \mathrm{~B} \mathrm{~b}$ \\
15.0 & $100.0 \mathrm{~A} \mathrm{a}$ & $100.0 \mathrm{~A} \mathrm{a}$ & $98.3 \mathrm{~A} \mathrm{a}$ & $88.0 \mathrm{~B} \mathrm{~b}$ \\
30.0 & $100.0 \mathrm{~A} \mathrm{a}$ & $99.5 \mathrm{~A} \mathrm{a}$ & $99.3 \mathrm{~A} \mathrm{a}$ & $99.8 \mathrm{~A} \mathrm{a}$ \\
60.0 & $100.0 \mathrm{~A} \mathrm{a}$ & $99.3 \mathrm{~A} \mathrm{a}$ & $99.5 \mathrm{~A} \mathrm{a}$ & $99.3 \mathrm{~A} \mathrm{a}$ \\
120.0 & $100.0 \mathrm{~A} \mathrm{a}$ & $100.0 \mathrm{~A} \mathrm{a}$ & $100.0 \mathrm{~A} \mathrm{a}$ & $99.8 \mathrm{~A} \mathrm{a}$ \\
480.0 & $100.0 \mathrm{~A} \mathrm{a}$ & $99.3 \mathrm{~A} \mathrm{a}$ & $100.0 \mathrm{~A} \mathrm{a}$ & $100.0 \mathrm{~A} \mathrm{a}$ \\
$\mathrm{F}_{\mathrm{sp}}=3.106^{*}$ & $100.0 \mathrm{~A} \mathrm{a}$ & $100.0 \mathrm{~A} \mathrm{a}$ & $99.8 \mathrm{~A} \mathrm{a}$ & $100.0 \mathrm{~A} \mathrm{a}$ \\
\hline
\end{tabular}

*Significant at $5 \%$ of probability; ${ }^{1}$ Means followed by the same letter, uppercase in the columns and lowercase in the rows, do not differ according to Scott-Knott's cluster test, with 5\% significance.

Source: Elaborated by the authors (2017).

Silva, Monquero and Munhoz (2015) reported weed differential susceptibility to saflufenacil at 7, 14 and 21 DAA. Between five weed species, I. purpurea was the most susceptible one, being completely controlled by saflufenacil at the rate of $25 \mathrm{~g} \mathrm{ha}^{-1}$. However, in the same work, rates superior than $50 \mathrm{~g} \mathrm{ha}^{-1}$ were necessary to control Merremia aegyptia by $80.0 \%$, which is also classified in Convolvulaceae family.

Considering other weed species, Vitorino et al. (2012) observed that control of Richardia brasiliensis with commercial rates of saflufenacil only became satisfactory after 14 DAA, occasion that control values overcame $89.0 \%$. 
At 28 DAA, flumioxazin efficacy was not different to previous evaluations, at which lower susceptibility of $I$. triloba and $I$. nil was detected at the rate of $3.75 \mathrm{~g} \mathrm{ha}^{-1}$, without differences between these species; at the rate of $7.5 \mathrm{~g} \mathrm{ha}^{-1}$, lower susceptibility of $I$. triloba was identified (Table 5).

Absolute control reached by all rates of saflufenacil resulted on the absence of dry matter, what did not allow collecting this variable in the plots (data not presented). For flumioxazin, only effect of herbicide rates was observed on dry matter, which rates equal to or higher than $15 \mathrm{~g} \mathrm{ha}^{-1}$ promoted total elimination of weeds, without difference between species (Table 6).

Frequently, reports of herbicide differential susceptibility are found regarding to weed species of the same genus. For Holt, Powles and Holtum (1993), mechanisms that plants developed to tolerate or to resist to a molecule are: lower herbicide absorption and/or translocation, higher metabolic capacity to convert an herbicide into less phytotoxic compounds, molecule compartmentalization, lack of herbicide affinity by the enzyme specific site of action and overproduction of the target enzyme.

Table 5 - Efficacy of flumioxazin on four weed species of Ipomoea genus, evaluated at 28 days after application (DAA) Machado/MG, 2017.

\begin{tabular}{|c|c|c|c|c|}
\hline \multirow{2}{*}{$\begin{array}{l}\text { Rates } \\
\left(\mathrm{g} \mathrm{ha}^{-1}\right)\end{array}$} & \multicolumn{4}{|c|}{ Species $^{1}$} \\
\hline & I. hederifolia & I. nil & I. quamoclit & 1. triloba \\
\hline Check Plots & $0.0 \mathrm{~B} \mathrm{a}$ & $0.0 \mathrm{C} \mathrm{a}$ & $0.0 \mathrm{~B} \mathrm{a}$ & $0.00 \mathrm{C} \mathrm{a}$ \\
\hline 3.75 & $100.0 \mathrm{~A} \mathrm{a}$ & $81.3 \mathrm{~B} \mathrm{~b}$ & $99.8 \mathrm{~A}$ a & $83.8 \mathrm{~B} \mathrm{~b}$ \\
\hline 7.5 & $100.0 \mathrm{~A} \mathrm{a}$ & $100.0 \mathrm{~A} \mathrm{a}$ & $99.8 \mathrm{~A}$ a & $80.0 \mathrm{~B} \mathrm{~b}$ \\
\hline 15.0 & $100.0 \mathrm{~A} \mathrm{a}$ & $100.0 \mathrm{~A} \mathrm{a}$ & $100.0 \mathrm{~A} \mathrm{a}$ & $100.0 \mathrm{~A} \mathrm{a}$ \\
\hline 30.0 & $100.0 \mathrm{~A} \mathrm{a}$ & $100.0 \mathrm{~A} \mathrm{a}$ & $100.0 \mathrm{~A} \mathrm{a}$ & $100.0 \mathrm{~A} \mathrm{a}$ \\
\hline 60.0 & $100.0 \mathrm{~A} \mathrm{a}$ & $100.0 \mathrm{~A} \mathrm{a}$ & $100.0 \mathrm{~A} \mathrm{a}$ & $100.0 \mathrm{~A} \mathrm{a}$ \\
\hline 120.0 & $100.0 \mathrm{~A} \mathrm{a}$ & $100.0 \mathrm{~A} \mathrm{a}$ & $100.0 \mathrm{~A} \mathrm{a}$ & $100.0 \mathrm{~A} \mathrm{a}$ \\
\hline 480.0 & $100.0 \mathrm{~A} \mathrm{a}$ & $100.0 \mathrm{~A} \mathrm{a}$ & $100.0 \mathrm{~A} \mathrm{a}$ & $100.0 \mathrm{~A} \mathrm{a}$ \\
\hline $\mathrm{F}_{\mathrm{sp}}=4.059 *$ & \multicolumn{2}{|c|}{$F_{\text {rate }}=527.094^{*}$} & $2.541^{*}$ & $\mathrm{CV}(\%)=7.07$ \\
\hline
\end{tabular}

* Significant at $5 \%$ of probability; ${ }^{1}$ Means followed by the same letter, uppercase in the columns and lowercase in the rows, do not differ according to Scott-Knott's cluster test, with 5\% significance.

Source: Elaborated by the authors (2017).

Table 6 - Percentage dry mass of four weed species of Ipomoea genus when submitted to different rates of flumioxazin, evaluated at 28 days after application (DAA). Machado/MG, 2017.

\begin{tabular}{|c|c|c|c|c|c|}
\hline \multirow{2}{*}{$\begin{array}{l}\text { Rates } \\
\left(\mathrm{g} \mathrm{ha}^{-1}\right)\end{array}$} & \multicolumn{4}{|c|}{ Species $^{1}$} & \multirow{2}{*}{ Means } \\
\hline & I. hederifolia & I. nil & I. quamoclit & 1. triloba & \\
\hline Check Plots & 100.0 & 100.0 & 100.0 & 100,0 & $100.0 \mathrm{C}$ \\
\hline 3.75 & 0.0 & 7.9 & 0.5 & 5,8 & $3.5 \mathrm{~B}$ \\
\hline 7.5 & 0.0 & 0.0 & 7.4 & 5,7 & $3.3 \mathrm{~B}$ \\
\hline 15.0 & 0.0 & 0.0 & 0.0 & 0,0 & $0.0 \mathrm{~A}$ \\
\hline 30.0 & 0.0 & 0.0 & 0.0 & 0,0 & $0.0 \mathrm{~A}$ \\
\hline 60.0 & 0.0 & 0.0 & 0.0 & 0,0 & $0.0 \mathrm{~A}$ \\
\hline 120.0 & 0.0 & 0.0 & 0.0 & 0,0 & $0.0 \mathrm{~A}$ \\
\hline 480.0 & 0.0 & 0.0 & 0.0 & 0,0 & $0.0 \mathrm{~A}$ \\
\hline $\mathrm{F}_{\mathrm{sp}}=0.921^{\mathrm{NS}}$ & \multicolumn{2}{|c|}{$F_{\text {rate }}=1.533 .691 *$} & $\mathrm{~F}_{\mathrm{int}}=1.210^{\mathrm{NS}}$ & \multicolumn{2}{|c|}{$\mathrm{CV}(\%)=26.81$} \\
\hline
\end{tabular}

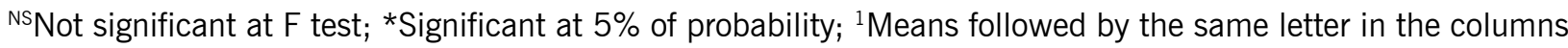
do not differ according to Scott-Knott's cluster test, with $5 \%$ significance.

Source: Elaborated by the authors (2017). 
Therefore, differential susceptibility of Ipomoea species was detected to bentazon (McCLELLAND et al., 1978; MATHIS; OLIVER, 1980) and to carfentrazone-ethyl (CHRISTOFFOLETI et al., 2006); species of Digitaria presented differential susceptibility to diuron (DIAS et al., 2003); species of Bidens were different to chlorimuron-ethyl and imazethapyr (LÓPEZ-OVEJERO et al., 2006); and species of Amaranthus were different to chlorimuron-ethyl and trifloxysulfuron-sodium (CARVALHO et al., 2006). In the case of saflufenacil and flumioxazin, efficacy of herbicides was so elevated that did not allow species differentiation, what lead the conclusion that commercial rates were completely adequate to all the Ipomoea species evaluated.

Species differential susceptibility has direct implications on the weed management to be adopted in an agricultural area (CARVALHO et al, 2006). Interspecific differences of susceptibility require correct identification of the weeds present in a crop field, especially for weeds on seedling stage, as consequence of the necessity of precise choice of the herbicides to be applied.

For sugarcane crop, several works have detached high importance, occurrence and difficult to control species from the Convolvuceae family, with special highlights to I. triloba (Christoffoleti et al., 2006; Kuva et al., 2007; Monquero et al., 2008).

Nicolai et al. (2013) obtained increasing levels of susceptibility for Ipomoea species submitted to flumioxazin, as follows: Merremia aegyptia < I. hederifolia < I. triloba < I. purpurea < Merremia cissoides; at which optimal rates to control $80.0 \%$ of each species were, respectively: $238.6,173.1$, 84.7, 43.8 and $16.8 \mathrm{~g} \mathrm{ha}^{-1}$.

This way, control results obtained in this study were considered completely satisfactory when analyzing the susceptibility of Ipomoea genus weed species to flumioxazin and saflufenacil. Rates below recommended on leaflets were enough to reach total control of the plants, so commercial rate may be considered adequate to all the species evaluated (I. hederifolia, I. nil, I. quamoclit and I. triloba).

\section{Conclusions}

Ipomoea genus weed species were completely controlled by the herbicides saflufenacil and flumioxazin, which may be considered excellent alternatives to control morning glory.

I. triloba and I. nil were identified as the least sensible species to flumioxazin at the rate of $3.75 \mathrm{~g} \mathrm{ha}^{-1}$; lower control of $I$. triloba was also identified with $7.5 \mathrm{~g} \mathrm{ha}^{-1}$ of flumioxazin; rates equal to or higher than $15 \mathrm{~g} \mathrm{ha}^{-1}$ promoted total control of weeds.

\section{Acknowledgments}

The authors would like to thank the Federal Institute of Education, Science and Technology of South of Minas Gerais, Campus Machado, for making this study possible.

\section{Suscetibilidade de quatro espécies de plantas daninhas do gênero Ipomoea aos herbicidas saflufenacil e flumioxazin}

\section{Resumo}

Dentre as plantas daninhas comumente encontradas no Brasil e que interferem diretamente na agricultura, destacam-se aquelas classificadas na família Convolvulaceae, particularmente no 
gênero Ipomoea L., popularmente conhecidas por corda-de-viola. Dentre os herbicidas registrados para o controle dessas plantas daninhas, encontram-se o flumioxazin e o saflufenacil. Neste contexto, este trabalho foi desenvolvido com o objetivo de avaliar a suscetibilidade de espécies de plantas daninhas do gênero Ipomoea aos herbicidas flumioxazin e saflufenacil. Dois experimentos semelhantes foram realizados em 2017, instalados em blocos ao acaso, com quatro repetições. Os tratamentos foram organizados em esquema fatorial $8 \times 4$, em que oito foram as doses de cada um dos herbicidas e quatro foram as espécies de plantas daninhas do gênero Ipomoea ( $/$. hederifolia, I. nil, I. quamoclit e I. triloba). Para o saflufenacil foi adotado (g ha-1): 0, 1,5; 3,0; 6,1; 12,3; 24,5; 49,0; 98,0; para flumioxazin foi adotado (g ha-1) 0; 3,75; 7,5; 15,0; 30,0; 60,0; 120,0; 480,0 . As espécies de plantas daninhas do gênero Ipomoea foram perfeitamente controladas pelos herbicidas saflufenacil e flumioxazin, que podem ser considerados como excelentes alternativas para controle de cordas-de-viola. Nas doses de 3,75 $\mathrm{g} \mathrm{ha}^{-1}$, detectou-se menor suscetibilidade de I. triloba e I. nil ao herbicida flumioxazin; na dose de 7,5 $\mathrm{g} \mathrm{ha}^{-1}$, o herbicida flumioxazin também promoveu menor controle de I. triloba; doses iguais ou superiores a $15,0 \mathrm{~g} \mathrm{ha}^{-1}$ promoveram eliminação total das plantas daninhas.

Palavras-chave: Protox. Corda-de-viola. Controle químico. Eficácia. Pós-emergência.

\section{References}

AUSTIN, D. F. Convolvulaceae. In: SMITH, N. P.; MORI, S. A.; HENDERSON, A.; STEVENSON, D. W.; HEALD, S. V. (eds.). Flowering plants of the Neotropics. Princeton University Press: New York Botanical Garden, 2004. p. 113-115.

CARVALHO, S. J. P.; BUISSA, J. A. R.; NICOLAI, M.; LÓPEZ-OVEJERO, R. F.; CHRISTOFFOLETI, P. J. Suscetibilidade diferencial de plantas daninhas do gênero Amaranthus aos herbicidas trifloxysulfuronsodium e chlorimuron-ethyl. Planta Daninha, v. 24, n. 3, p. 541-548, 2006.

CHRISTOFFOLETI, P. J.; BORGES, A.; NICOLAI, M.; CARVALHO, S. J. P.; LÓPEZ-OVEJERO, R. F.; MONQUERO, P. A. Carfentrazone-ethyl aplicado em pós-emergência para o controle de Ipomoea spp. e Commelina benghalensis na cultura da cana-de-açúcar. Planta Daninha, v. 24, n. 1, p. 83-90, 2006.

CHRISTOFFOLETI, P. J.; CARVALHO, S. J. P.; LÓPEZ-OVEJERO, R. F.; NICOLAI, M. Métodos para comprovação da resistência de plantas daninhas a herbicidas. In.: MONQUERO, P. A. (Org.) Experimentação com herbicidas. São Carlos: RiMa Editora, 2016. p. 99-118.

DIAS, N. M. P.; REGITANO, J. B.; CHRISTOFFOLETI, P. J.; TORNISIELO, V. L. Absorção e translocação do herbicida diuron por espécies suscetível e tolerante de capim-colchão (Digitaria spp.). Planta Daninha, v. 21, n. 2, p. 293-300, 2003.

HAO, G. F.; ZUO, Y.; YANG, S. G.; YANG, G. F. Protoporphyrinogen oxidase inhibitor: an ideal target for herbicide discovery. Chemistry in China, v. 65, n. 12, p. 961-969, 2011.

HOLT, J. S. ; POWLES, S. B. ; HOLTUM, J. A. M. Mechanisms and agronomic aspects of herbicide resistance. Annual Review of Plant Biology, v. 44, p. 203-229, 1993. 
KUVA, M. A.; PITELLI, R. A.; SALGADO, T. P.; ALVES, P. L. C. A. Fitossociologia de comunidades de plantas daninhas em agro ecossistema cana-crua. Planta Daninha, v. 25, n. 3, p. 501-511, 2007.

LÓPEZ-OVEJERO, R. F.; CARVALHO, S. J. P.; NICOLAI, M.; ABREU, A. G.; GROMBONE-GUARATINI, A. T.; TOLEDO, R. E. B.; CHRISTOFFOLETI, P. J. Resistance and differential susceptibility of Bidens pilosa and B. subalternans biotypes to ALS-inhibiting herbicides. Scientia Agricola, v. 63, n. 2, p. 139-145, 2006.

MATHIS, W. D.; OLIVER, L. R. Control of six morningglory (Ipomoea) species in soybeans (Glycine max). Weed Science, v. 28, n. 4, p. 409-415, 1980.

MAYO, C. M.; HORAK, M. J.; DALLAS, P. E.; BOYER, J. E. Differential control of four Amaranthus species by six postmergence herbicides in soybean (Glycine max). Weed Technology, v. 9, n.1, p. 141-147, 1995.

McCLELLAND, M. R.; OLIVER, L. R.; MATHIS, W. D.; FRANS, R. E. Responses of six morningglory (Ipomoea) species to bentazon. Weed Science v. 26, n. 5, p. 459-464, 1978.

MEROTTO JÚNIOR, A.; VIDAL, R. A. Herbicidas inibidores da PROTOX. In: VIDAL, R. A.; MEROTTO JÚNIOR, A. (Ed.). Herbicidologia. Porto Alegre: UFRGS, 2001. p. 69-86.

MONQUeRO, P. A.; AMARAL, L. R.; BINHA, D. P.; SILVA, P. V.; SILVA, A. C.; MARTINS, F. R. A. Mapas de infestação de plantas daninhas em diferentes sistemas de colheita de cana-de-açúcar. Planta Daninha, v. 26, n. 1, p. 47-55, 2008.

NICOLAI, M.; OBARA, F. E. B.; MELO, M. S. C.; SOUZA JÚNIOR, J. A.; CANTALICE-SOUZA, R.; CHRISTOFFOLETI, P. J. Suscetibilidade diferencial de espécies convolvuláceas ao flumioxazin determinada através de curvas de dose-resposta. Planta Daninha, v. 31, n. 1, p. 157-163, 2013.

RODRIGUES, B. N.; ALMEIDA, F. S. Guia de herbicidas. 6. ed. Londrina: Grafmarke, 2011. 697p.

SALAS, R. A.; BURGOS, N. R.; TRANEL, P. J.; SINGH, S.; GLASGOW, L.; SCOTT, R. C.; NICHOLS, R. L. Resistance to PPO-inhibiting herbicide in Palmer amaranth from Arkansas. Pest Management Science, v. 72, n. 5, p. 864-869, 2016.

SCOTT, A. J.; KNOTT, M. A. A cluster analysis method for grouping means in the analysis of variance. Biometrics, v. 30, n. 3, p. 507-512, 1974.

SCOTT, S. M.; VAN DEYNZE, B. Hoes to herbicides: economics of evolving weed management in the United States. European Journal of Development Research, v. 29, n. 3, p. 560-574, 2017.

SILVA, P. V.; MONQUERO, P. A.; MUNHOZ, W. S. Controle em pós-emergência de plantas daninhas por herbicidas utilizados na cultura da cana-de-açúcar. Revista Caatinga, v. 28, n. 4, p. 21-32, 2015.

SOCIEDADE BRASILEIRA DA CIÊNCIA DAS PLANTAS DANINHAS - SBCPD. Procedimentos para instalação, avaliação e análise de experimentos com herbicidas. Londrina: SBCPD, 1995. 42 p.

SOUZA, V. C.; LORENZI, H. Botânica sistemática: guia ilustrado para identificação das famílias de Angiospermas da flora brasileira. 3 ed. Nova Odessa: Instituto Plantarum, 2005. 640 p. 
STAPLES, G. W.; BRUMMITT, R. K. Convolvulaceae. In: HEYWOOD, V. H.; BRUMMITT, R. K.; CULHAM, A.; SEBERG, O. (Eds.). Flowering plant families of the world. Kew: Royal Botanic Gardens, 2007. p. 108-110.

VASCONCELOS, M. C. C.; SILVA, A. F. A.; LIMA, R. S. Interferência de plantas daninhas sobre plantas cultivadas. Agropecuária Científica no Semiárido, v. 8, n. 1, p. 1-6, 2012.

VIDAL, R. A.; MEROTTO JÚNIOR, A.; FLECK, N. G. Resistência de plantas daninhas aos herbicidas de menor risco para desenvolver problemas. CURSO DE MANEJO E RESISTÊNCIA DE PLANTAS DANINHAS AOS HERBICIDAS, 2., Ponta Grossa, 1999. Anais... Ponta Grossa: AEACG, 1999. p.68-72.

VITORINO, H. S.; MARTINS, D.; COSTA, S. Í. A.; MARQUES, R. P.; SOUZA, G. S. F.; CAMPOS, C. F. Eficiência de herbicidas no controle de plantas daninhas latifoliadas em mamona. Instituto Biológico de São Paulo, v. 79, n.1, p. 129-133, 2012.

Received in: June 17, 2019

Accepted in: January 14, 2020 